\title{
Religiãão e preferênncias econômicas e políticas entre jovens universitários da periferia: um estudo exploratório na Baixada Fluminense
}

Georges Gérard Flexor* Adrianno Oliveira Rodrigues* Robson Dias da Silva*

\section{Resumo}

O artigo procura analisar a importância da religião nas preferências políticas, sociais e econômicas entre os jovens universitários da periferia do Rio de Janeiro. Os dados são o resultado da aplicação de um survey recolhendo as opiniões de estudantes dos cursos de graduação de um campus da Universidade Federal Rural do Rio de Janeiro (UFRRJ), localizado em Nova Iguaçu, no coração da baixada fluminense. Uma análise multivariada (análise de componentes principais, clusters kmeans e regressão) dos dados do survey destaca a influência significativa das igrejas evangélicas em diversos assuntos de cunho moral. A pesquisa identifica também uma ampla e difusa demanda por políticas sociais e melhor provisão de bens públicos como saúde e educação.

Palavras-chave: religião, evangélicos, jovens, periferia urbana, survey.

\footnotetext{
* Universidade Federal Rural do Rio de Janeiro, Seropédica, RJ, Brasil.
} 


\title{
Religion and economic and political preferences among university students from the periphery: an exploratory study in the Baixada Fluminense
}

\begin{abstract}
This article aims to analyze the importance of religion on political, social and economic preferences among undergraduate students in the periphery of Rio de Janeiro. The data are the result of a survey on the opinions of undergraduate students from a campus of the Federal Rural University of Rio de Janeiro (UFRRJ), located in Nova Iguaçu, in the heart of Baixada Fluminense (Rio de Janeiro, Brazil). A multivariate analysis (principal component analysis, kmeans clusters and regression) of the survey data highlights the significant influence of evangelical churches on various moral issues. The research also identifies a broad and diffuse demand for social policies and better provision of public goods such as health and education.
\end{abstract}

Keywords: religion, evangelicals, youth, urban periphery, survey.

cordar antes do nascer do sol, enfrentar o desconforto de ônibus
lotados e engarrafamentos; sofrer a sensação de insegurança e
impotência frente à má qualidade de serviços públicos; desdobrar-se para combinar trabalho, estudos e vida social; equilibrar convicções morais e religiosas nos mais diferentes planos da vida; sonhar com um futuro melhor etc. Eis alguns pontos presentes no cotidiano de muitos jovens universitários das periferias metropolitanas brasileiras. Nessa batalha diária para viver e ser feliz, esses universitários contam muitas vezes com o apoio da religião e da razão. Por meio destas, conversam sobre política, se posicionam sobre temas polêmicos, formam suas crenças normativas sobre o certo e o errado e elaboram expectativas acerca das consequências de suas escolhas e dos eventos políticos, econômicos e sociais que permeiam o noticiário do país.

Tendo por base o cenário acima delineado, este artigo objetiva proporcionar uma maior compreensão quantitativa das atitudes desses universitários e apurar em que medida as denominações religiosas respondem por suas preferências. De modo mais específico, o texto procura entender como a identidade religiosa desses jovens se posiciona em relação 
a temas que estruturam parte da onda conservadora que atualmente agita politicamente o Brasil (Almeida, 2017; Villazón, 2014). Busca ainda mapear suas preferências a respeito do papel do Estado na organização da vida econômica e da oferta de bens públicos. Para tanto, o trabalho apresenta o resultado de um survey realizado com estudantes de cursos de graduação do Instituto Multidisciplinar (IM) da Universidade Federal Rural do Rio de Janeiro (UFRRJ), localizado em Nova Iguaçu, maior município da Baixada Fluminense ${ }^{1}$.

O texto está dividido em quatro partes, além desta introdução. Primeiramente, faz-se breve revisão da literatura especializada sobre as mudanças recentes pelas quais o Brasil tem passado em termos de composição religiosa da sua população. Na seção seguinte, há a descrição do material e métodos analisados, com a análise estatística utilizada. Segue-se apresentando e fazendo a discussão dos principais resultados alcançados. Por fim, destacam-se as principais conclusões, apontamentos e limitações encontradas.

\section{Religiões no Brasil: dinâmicas recentes}

As últimas décadas têm sido marcadas por significativas mudanças no perfil religioso da população brasileira (Mariano, 2013; Menezes, 2012; Teixeira, 2013; Teixeira; Menezes, 2014; Jacob; Hees; Waniez, 2013). O Censo de 2010 aponta que o Brasil ainda é um país majoritariamente católico, todavia, a rápida e continuada proliferação de denominações evangélicas pelo território nacional tem levado ao declínio relativo (percentual) da igreja católica na matriz religiosa brasileira (Mariano, 1999). Segundo os dados dos censos demográficos do Instituto Brasileiro de Geografia e Estatística (IBGE), os católicos representavam 83\% da população em 1990,

\footnotetext{
${ }^{1}$ Além de trazer informações e conhecimentos sobre uma população pouco estudada, o artigo lança alguma luz sobre a relação entre atitudes e religião entre os jovens do segmento social denominado "nova classe média brasileira" (Neri, 2011; Souza, 2012; Scalon; Salata, 2012; Uchoa; Kerstenetzky, 2012), um grupo social política e economicamente estratégico. Como se poderá notar na apresentação dos dados, os estudantes membros das classes de renda familiar $C$ e $D$, os estratos básicos da nova classe média, representam cerca de dois terços dos informantes da amostra.
} 
73,6\% em 2000 e 64,6\% em 2010. Os censos mostram também o rápido crescimento dos evangélicos e, de forma mais lenta, dos sem religião. Os evangélicos constituíam 9\% da população brasileira em 1990, 15,4\% em 2000 e 22,3\% em 2010.

O avanço evangélico tem sido notado com maior vigor nas principais regiões metropolitanas brasileiras, com especial atenção para as do Rio de Janeiro e de São Paulo (Alves et al., 2017). Ainda que não se possa afirmar ser esse um fenômeno exclusivamente metropolitano, evidências apontam que as periferias das grandes metrópoles têm se destacado como territórios privilegiados da expansão evangélica, ampliando seu raio de ação com a construção de templos espacialmente descentralizados e de tamanhos diversos. Tanto a Igreja Católica, quanto as religiões de matriz afrodescendente têm enfrentado a perda de espaço, muitas vezes em sentido literal, para denominações evangélicas, em especial, pentecostais e neopentecostais.

O crescimento dos sem religião é outra dinâmica religiosa destacada por vários autores (Mariano, 2013; Jacob; Hees; Waniez, 2013, Camurça, 2013). Correspondiam a 4,7\% da população brasileira em 1990, 7,4\% em 2000 e 8\% em 2010. Para a teóloga Maria Clara Bingemer (apud Camurça, 2013), a queda do número de católicos beneficiou, antes de mais nada, a expansão dos sem religião, sinalizando uma relação entre retração da igreja católica romana e secularização. Mariano (2013) sustenta que esse grupo sem vínculo institucional com uma religião é constituído principalmente por jovens e apresenta valores e crenças que os diferenciam dos grupos sociais brasileiros com vínculos com uma religião.

\section{Expansão pentecostal}

Em diversos artigos, Mariano $(2011$; 2008) nota que a expansão pentecostal no Brasil resulta tanto de fatores macrossociológicos quanto da própria dinâmica da oferta religiosa desencadeada pelo fim do monopólio católico. Segundo o sociólogo alemão Willems (apud Mariano, 2008), a rápida expansão das seitas pentecostais durante o intenso processo 
de transformação social dos anos 1950 deriva de sua capacidade de proporcionar sentidos e valores a grupos sociais desenraizados.

Para outro autor clássico da expansão pentecostal na América Latina, Lalive D'Epinay (apud Mariano, 2008), o crescimento dessa religião reside na sua capacidade de recriar relações tradicionais agrárias num contexto urbano. O pentecostalismo garante, dessa forma, certa continuidade cultural e moral às populações que deixaram seu universo rural e agrário para tentar sobreviver nas grandes cidades. Ou seja, o crescimento do pentecostalismo nesse período foi impulsionado pelo processo de urbanização e pelo êxodo rural, os mais pobres encontrando no pentecostalismo uma forma de recriar laços de solidariedade. Nesse sentido, portanto, a expansão pentecostal seria uma resposta à anomia vivenciada por populações carentes, pobres e mulheres, principalmente.

Chesnut (2003) observa, no entanto, que a rápida difusão do pentecostalismo nos segmentos mais marginalizados da sociedade brasileira se deve ao fato de que, para essas populações, o custo de oportunidade de se abandonar suas religiões nativas não se apresentaria tão elevado. Para este autor, deixar de ser católico e se tornar evangélico não implicaria grandes prejuízos sociais ou espirituais para esses grupos sociais. Como parte de seu argumento, sustenta que, se não fosse assim, provavelmente, o pentecostalismo não teria tido o sucesso apresentado, já que nas classes privilegiadas, para as quais o custo de mudança de religião é mais alto, o percentual de católicos não mostrou redução.

Para Chesnut e outros autores que adotam a perspectiva da economia da religião (lannaccone, 1998; Stark, 2009), a dinâmica religiosa é, sobretudo, determinada pelo lado da oferta, isto é, pelas condições de concorrências no mercado das religiões, pelos produtos religiosos ofertados, pelas estratégias de crescimento das igrejas etc. A expansão pentecostal que reflete um maior pluralismo religioso é, nessa perspectiva, o resultado do fim do monopólio católico, de sua estrutura de custo relativamente econômica, de seus investimentos em meios de comunicação, tais como rádio, televisão e mídias digitais que facilitariam a comercialização e o acesso a seus produtos e serviços (cultos, possibilidade de "cura" para problemas sociais, relação 
direta com o Espirito Santo). Assim, foram esses os principais recursos, todos do lado da oferta, que permitiram o crescimento das igrejas pentecostais e neopentecostais, como a Igreja Universal (Mariano, 2004).

\section{Evangélicos, opinião pública e política}

Como observa Gill (2004), considerando que a população evangélica da América Latina prega os valores da frugalidade, confiabilidade e responsabilidade pessoal, a princípio, é de se esperar que a influência dessa nova população protestante tenha o impacto previsto por Weber em A ética protestante e o espírito do capitalismo. A ênfase na conexão direta com o Espírito Santo, segundo este autor, favoreceria valores individualistas e o laissez-faire capitalista. Por outro lado, Smith (2018) observa que, em teoria, a expansão evangélica, pentecostal em particular, promoveria certa apatia política e favoreceria o status quo conservador, fato explicativo, por exemplo, de sua posição "apolítica" durante o período dos governos militares no país. Mariano (2016), ademais, reforça que o crescimento dessas denominações religiosas seria uma clara força política favorável às pautas mais conservadoras, em especial no campo moral (costumes e crenças).

No entanto, Gill (2004) nota que a análise dos dados estatísticos não revela impactos significativos da expansão evangélica nas atitudes dos crentes quando comparados com aquelas dos seguidores de outras religiões. Num estudo realizado na região metropolitana de São Paulo, Bohn (2004) confirma que é difícil classificar as opiniões dos grupos evangélicos como sendo de direita ou de esquerda. Destaca, por exemplo, que nas eleições presidenciais de 2002, o eleitorado evangélico votou majoritariamente em um candidato evangélico, Anthony Garotinho, que tinha plataforma política oscilando entre propostas que poderiam ser consideradas progressistas e conservadoras, dentro da ciência econômica².

Em estudos posteriores, Bohn (2007) mostra que os evangélicos optaram em grande medida pelo voto no então candidato do Partido dos

\footnotetext{
${ }^{2}$ No município de Nova Iguaçu, por exemplo, o presidente eleito Jair Messias Bolsonaro recebeu 72,48\% dos votos válidos no segundo turno. De 2002 a 2014, os candidatos de esquerda, Luiz Inácio Lula da Silva e Dilma Rousseff, foram os mais votados.
} 
Trabalhadores, Luiz Inácio Lula da Silva, seguindo orientações de Anthony Garotinho em 2002, mas não manifestaram um padrão de voto preciso na eleição de 2006, marcada pela ausência de candidatura evangélica competitiva. Para a autora, isso pode ser um indicativo de que os eleitores evangélicos são antes um grupo de identidade do que um grupo de interesse, isto é, tendem a votar fundamentalmente em candidatos associados às suas igrejas ou naqueles que têm boa reputação entre as autoridades e participantes de seus lugares de cultos.

Análises do comportamento político dos evangélicos mostram que eles têm desempenhado uma influência crescente na cena nacional. Peixoto e Rennó (2011), por exemplo, analisaram os determinantes de voto na candidata Dilma Rousseff, no primeiro e no segundo turnos das eleições presidenciais de 2010. Concluem que o pertencimento a uma classe social pouco impactou no voto a favor ou contra a candidata do Partido dos Trabalhadores. Salientam, por outro lado, o efeito das denominações religiosas, em particular o comportamento eleitoral dos evangélicos, que, em sua maioria, votaram contra a candidata.

A atuação política das igrejas pentecostais é outro aspecto do pluralismo religioso que vem recebendo destaque na literatura especializada. Lacerda (2017) e Lacerda e Brasiliense (2018) mostram que houve um crescimento do número de deputados evangélicos no Brasil nas últimas décadas. No entanto, observam que o número desses deputados é bastante inferior ao seu peso eleitoral. Notam também que o aumento do número de deputados evangélicos se deve principalmente ao esforço concentrado de um grupo restrito de igrejas pentecostais. Como destacam Lacerda e Brasiliense (2018, p. 173), "se existe uma 'força eleitoral' evangélica, ela reside apenas nas 'candidaturas oficiais' pentecostais".

\section{Expansão evangélica e juventude}

A juventude brasileira não permaneceu alheia às mudanças religiosas. Mariano (2013) observou que os jovens representam uma percentagem significativa dos sem religião e diversos estudos mostram que a expansão 
evangélica teria influência sobre as atitudes dos jovens das periferias brasileiras. Por exemplo, Fernandes (2011), baseando-se numa pesquisa realizada com jovens da Baixada Fluminense, constata que os vínculos entre juventude e religião são bastante importantes nas periferias das grandes cidades brasileiras. A autora argumenta que "há que se refutar a tese do indiferentismo religioso da juventude" (Fernandes, 2011, p. 121). No tocante aos jovens pentecostais, observa, eles tendem a ser moralmente mais conservadores do que os católicos em questões como o consumo de álcool ou sexo antes do casamento. Além disso, expressam uma demanda por educação e ações que possam reduzir a pobreza e a violência. No entanto, a autora destaca que eles não têm boas expectativas quanto à possibilidade de se resolverem os problemas que afligem seus cotidianos, e que, para muitos, de forma mais pronunciada os pentecostais, "mudança social" dependeria do fortalecimento da crença em Deus.

\section{Os dados}

Postas as considerações anteriores, busca-se com este trabalho contribuir para a melhor compreensão do fenômeno associado à expansão pentecostal (e neopentecostal) entre a juventude brasileira, em especial nas regiões periféricas, socialmente carentes, dos grandes e importantes centros econômicos e urbanos nacionais. Os resultados do trabalho são frutos de pesquisa realizada junto à comunidade discente dos cursos de Graduação do Instituto Multidisciplinar da Universidade Federal Rural do Rio de Janeiro (IM-UFRRJ), localizado em Nova Iguaçu, mais importante centro econômico e político da Baixada Fluminense ${ }^{3}$. O IM-UFRRJ é um dos três campi da UFRRJ dedicados ao ensino, pesquisa e extensão, atendendo cerca de 3.000 alunos em diferentes cursos de graduação e pós-graduação.

As informações da pesquisa foram obtidas a partir da aplicação eletrônica de um survey entre abril e junho de 2017. Os informantes

${ }^{3} \mathrm{~A}$ Universidade Federal Rural do Rio de Janeiro criou, no âmbito do programa de expansão do ensino superior no Brasil no governo Lula da Silva, o REUNI, dois campi fora da sede, um na cidade de Três Rios, interior fluminense e outro na cidade de Nova Iguaçu, na região metropolitana do Rio de Janeiro. 
eram universitários regularmente matriculados em algum dos cursos de graduação do Instituto.

Esperava-se que a experiência da vida universitária, via valorização do debate econômico, político e social, impactasse as opiniões desses jovens, levando-os a manifestar atitudes ao mesmo tempo mais progressistas e informadas do que as atitudes medianas da população da periferia do Rio de Janeiro, região que majoritariamente votou no então candidato conservador Jair Messias Bolsonaro na eleição presidencial de 2018. Do mapeamento dessas preferências, espera-se, ademais, o entendimento de forma original e inovadora do papel da identidade religiosa na formação de atitudes em um contexto onde a expansão evangélica e a insegurança econômica e social são marcantes. Espera-se, assim, que esses dados indiquem tendências sobre o comportamento de parcela importante do eleitorado brasileiro.

Do ponto de vista do tratamento dos dados, cabe destacar que dos 384 formulários respondidos, 20 foram descartados por apresentarem elevado número de questões não respondidas. No tocante à distribuição das respostas, os cursos de bacharelado apresentaram maior percentual somado, sendo, em ordem: Turismo (17,6\%), Ciências Econômicas (15,5\%), Administração de Empresas (11,1\%) e Direito (10,5\%). Dentre as licenciaturas, Pedagogia (11,8\%), História (11,1\%) e Geografia (10,6\%) se destacam, tendo Letras e Matemática percentuais bem menores, assim como Ciências da Computação, único curso da área de Tecnologias.

Vale destacar que do conjunto de respostas se infere que a grande maioria dos respondentes são moradores de municípios da Baixada Fluminense ou de bairros mais pobres da Zona Norte da cidade do Rio de Janeiro. São, principalmente, jovens, entre 18 e 25 anos (66,8\%) e entre 25 e 35 anos (21,3\%). A maior parte se declara como brancos (45\%), seguidos por pardos $(34,1 \%)$ e negros $(17,5 \%)$. Muitos já possuem algum tipo de renda $(57,8 \%)$ e esperam, ao cursar a UFRRJ, ter melhores oportunidades de trabalho $(73,7 \%)$.

Além de buscar dados nominais, tais como denominações religiosas, cor, idade, gênero ou classe de renda familiar, o survey procurou informações 
sobre as preferências sociais, políticas e econômicas dos alunos. Para capturar essas preferências, foram elaboradas questões solicitando aos informantes seus graus de concordância com quatro conjunto de temas:

1) questões relacionadas à legalização do aborto, ao casamento de pessoas do mesmo sexo ou à liberalização do uso recreativo de maconha. Uma hipótese inicial, baseada na literatura mencionada anteriormente, era de que os jovens evangélicos apresentassem opiniões mais conservadoras do que os não evangélicos;

2) questões relacionadas à tensão entre o indivíduo e o grupo, principalmente a família. Nesse quesito, esperava-se que os jovens evangélicos valorizassem mais a centralidade e importância do grupo e da família;

3) questões que visam proporcionar informações acerca do posicionamento dos jovens em matéria de políticas sociais. A expectativa inicial era de que não existisse diferenças significativas entre os jovens pertencentes às diferentes denominações. Como apontou Fernandes (2011), há uma ampla e difundida demanda por educação, saúde e outros bens públicos;

4) questões relativas ao papel do Estado e do mercado na promoção do desenvolvimento. Para essas questões, a pressuposição era de que os universitários evangélicos adotassem posicionamento mais pró-mercado, em consonância com o apregoado por grupos conservadores que têm se mostrado bem recebidos por esse grupo social.

O registro das preferências usou escala de 1 a 10. Com este método de produção de dados, procurou-se obter uma medida quantitativa das preferências. Além de oferecer um retrato das preferências dos diversos grupos, os dados ordinais possibilitam o recurso a testes e análises estatísticas multivariadas.

Iniciamos o tratamento dos dados com a análise dos componentes principais (Principal Component Analysis) no intuito de diminuir o número de variáveis em análise e explorar a estrutura de preferências latentes. Em seguida, foi realizada análise de agrupamento (kmeans) para classificar a 
população objeto da pesquisa e analisar como as denominações religiosas impactam essa classificação e suas relações com os componentes extraídos.

Os dados obtidos pela pesquisa não podem, evidentemente, ser generalizados para estabelecer inferências sobre posicionamentos e valores de populações mais abrangentes, como, por exemplo, toda a população da Baixada Fluminense. No entanto, as opiniões e preferências coletadas pela pesquisa permitem apontar tendências que provavelmente ganharão mais força nos próximos anos.

\section{Discussão dos resultados}

Como pode ser observado na tabela 1, é elevada a presença de evangélicos entre os estudantes que participaram do survey. Os dados indicam que 35,99\% dos informantes se declaram evangélicos (categoria E). Depois desses, os grupos religiosos mais representados são os católicos (categoria C), com 14,29\%, seguidos por aqueles que declaram não se vincularem a uma única religião e reivindicam múltiplos pertencimentos (categoria MR), com 9,34\%, e os seguidores do espiritismo kardecista (categoria K), com 5,22\%. A pesquisa identificou ainda a presença de um pequeno grupo de informantes vinculados a religiões afrobrasileiras (categoria Afro $)^{4}$. Cabe destacar ainda o número elevado de estudantes sem religião (categoria SR) e o fato de que um pouco menos da metade deles acreditam em alguma espiritualidade ${ }^{5}$.

Tabela 1 - Religiões informadas (\%)

\begin{tabular}{|c|c|c|c|c|c|}
\hline $\mathbf{C}$ & $\mathbf{E}$ & $\mathbf{K}$ & MR & Afro & SR \\
\hline 14,29 & 35,99 & 5,22 & 9,34 & 4,12 & 31,04 \\
\hline
\end{tabular}

Fonte: elaborada pelos autores com base nos dados do survey.

${ }^{4}$ Umbanda e Candomblé.

${ }^{5}$ Os ateus declarados representam $16,57 \%$ da amostra. 
É importante contrastar esses dados com a participação relativa das diferentes denominações religiosas nos principais municípios da Baixada Fluminense. Segundo o censo de 2010, em Nova Iguaçu, 33\% da população se declarava católica, 36,94\% evangélica, 21,17\% sem religião, 2,63\% espírita, 1\% de religiões afrobrasileiras e 0,44\% sem religião determinada. Nos demais municípios, a distribuição é bem semelhante. Assim, nota-se que o perfil religioso dos estudantes do IM segue padrão que reflete algumas das principais tendências da dinâmica religiosa apontada: 1) a força das igrejas evangélicas nas periferias das grandes cidades e; 2) o peso dos sem religião entre os jovens.

\section{Religião e renda}

Em termos de renda, a Baixada Fluminense é um espaço heterogêneo, com grande disparidade de renda familiar e onde predominam os grupos socioeconômicos mais desfavorecidos. Essa característica se encontra entre os alunos que participaram do survey, como mostrado na tabela 2. As classes C e D representam a condição familiar de $64 \%$ dos estudantes. Cabe também destacar uma percentagem elevada de membros de famílias de renda muito baixa (classe $\mathrm{E}$ ) e um pequeno contingente de alunos pertencentes a famílias de renda média-alta (classe B).

Tabela 2 - Estratos de renda familiar (\%)

\begin{tabular}{|c|c|c|c|}
\hline B & C & D & E \\
\hline 9,34 & 28,30 & 35,99 & 26,37 \\
\hline
\end{tabular}

Fonte: Elaboração própria a partir dos dados do survey.

Por sua vez, "religião" é variável presente em todos os grupos socioeconômicos. A tabela 3 mostra que os evangélicos são o grupo mais representativo em todos os extratos de renda familiar. Com a exceção da classe B, em que predominam os sem religião, os evangélicos são mais numerosos e têm maior peso relativo em todos os grupos. Em especial, 
o fato de observar-se, nos resultados do survey, uma elevada presença relativa de evangélicos nessas classes pode sugerir, como já ressaltaram Bohn (2004), Mariano (2013) e outros, uma possível associação entre famílias de renda mais baixa e essa denominação. No entanto, o teste Chi-quadrado de independência não sinaliza associação e, como pode ser observado, o peso relativo dos sem religião é também expressivo nos estratos de renda familiar mais baixo.

Tabela 3 - Relação entre religião x renda (\% segundo a renda)

\begin{tabular}{|c|c|c|c|c|}
\hline & B & C & D & E \\
\hline C & 12,90 & 15,00 & 15,38 & 12,09 \\
\hline E & 25,81 & 39,00 & 37,61 & 35,16 \\
\hline K & 16,13 & 5,00 & 5,13 & 3,30 \\
\hline MR & 9,68 & 10,00 & 7,69 & 10,99 \\
\hline Afro & 6,45 & 4,00 & 3,42 & 4,40 \\
\hline SR & 29,03 & 27,00 & 30,77 & 34,07 \\
\hline \multicolumn{5}{|c|}{ Test for independence of all factors: } \\
\hline
\end{tabular}

Fonte: Elaboração própria a partir dos dados do survey.

\section{Religiosidade}

Se considerarmos, como Azzi e Ehrenberg (1975), a frequência com que as pessoas vão às suas igrejas e outros espaços de culto como uma proxy da religiosidade, o survey aponta para a existência de um padrão marcado, por um lado, por um grupo caracterizado por uma forte religiosidade, que comparece à igreja ou congênere semanalmente (categoria EW), ou frequentemente, duas ou três vezes por mês (categoria AF) e, por outro lado, por um grupo pouco religioso, que nunca visita uma igreja (categoria N) e quando o faz, o faz raramente (categoria R) ou no máximo uma vez a cada dois ou três meses (categoria ST) (tabela 4). 
Tabela 4 - Religiosidade (em \%) segundo o nível de frequência ao lugar de culto

\begin{tabular}{|c|c|c|c|c|}
\hline AF & EW & N & R & ST \\
\hline 8,52 & 31,59 & 30,22 & 20,60 & 9,07 \\
\hline
\end{tabular}

Fonte: Elaboração própria a partir dos dados do survey.

Os dados do survey indicam que os evangélicos apresentam maiores níveis de religiosidade, esta entendida como hábito de professar a fé em espaços físicos próprios (tabela 5). Pode-se sinalizar que mais de 75\% dos evangélicos visitam suas igrejas toda semana ou frequentemente, duas a três vezes por mês. Em comparação, mais da metade dos católicos informaram visitar sua igreja raramente ou somente poucas vezes. Como é de se esperar, os sem religião apresentam o menor nível de religiosidade (82,52\% deles afirmaram nunca comparecer em igreja ou outro lugar de culto).

Tabela 5 - Religião x religiosidade (em \% segundo a religião)

\begin{tabular}{|c|c|c|c|c|c|}
\hline & AF & EW & N & $\mathbf{R}$ & ST \\
\hline C & 13,46 & 30,76 & 3,84 & 32,69 & 19,23 \\
\hline $\mathbf{E}$ & 9,92 & 66,41 & 3,05 & 10,68 & 9,92 \\
\hline K & 5,26 & 21,05 & 15,78 & 42,10 & 15,79 \\
\hline MR & 5,88 & 11,76 & 17,64 & 52,94 & 11,76 \\
\hline Afro & 46,66 & 20,00 & 6,66 & 13,33 & 13,33 \\
\hline SR & 0,88 & 0,88 & 83,18 & 14,15 & 0,88 \\
\hline \multicolumn{7}{|c|}{ Test for independence of all factors: } \\
\hline
\end{tabular}

Fonte: Elaboração própria a partir dos dados do survey.

\section{A estrutura das preferências}

Extrair uma estrutura de preferência das variáveis selecionadas para capturar os valores e atitudes políticas e sociais expressadas no survey requer 
uma técnica estatística capaz de agrupar variáveis fortemente correlacionadas para formar novas variáveis que representam a estrutura latente desses valores e atitudes. A Análise dos Componentes Principais serve a este objetivo. A aplicação dessa técnica estatística ao conjunto de variáveis que representam as diferentes atitudes informadas pelos estudantes permite mapear uma estrutura de preferência que tem seis componentes como pilares.

O primeiro componente (ver tabela 6) traduz o que pode ser denominado agenda liberal de costume: relaciona-se com atitudes a respeito de legalização do aborto, casamento de pessoas do mesmo sexo, liberalização da maconha e descriminalização das drogas. Como pode ser observado no gráfico 1, a distribuição dos escores desse componente é positivamente enviesada ${ }^{6}$. Em outras palavras, a maioria dos estudantes compartilha os valores progressistas da "agenda dos costumes liberais". A análise desse componente mostra ainda que quem adere a esta agenda tende a se posicionar a favor de políticas de transferências de renda como o Bolsa Família e contra a ideia de que o homem deve ser "naturalmente o chefe de família".

Apesar de apontar para uma maioria de estudantes compartilhando valores mais progressistas, a distribuição dos escores sinaliza também que há um elevado número de estudantes que são contrários à legalização do aborto, ao casamento de pessoas do mesmo sexo ou à liberalização da maconha. A questão da interrupção voluntária da gravidez é, em particular, um tema sensível que muitos estudantes rejeitam.

O segundo componente (ver tabela 6) agrupa variáveis que procuram traduzir o apoio ao maior envolvimento do Estado na provisão de bens públicos como educação e saúde, assim como na melhoria da renda e redução das desigualdades econômicas. Manifesta o que pode ser chamado de uma demanda por políticas públicas e proteção social. Esta é a dimensão das preferências sociais, políticas e econômicas mais consensual entre os jovens que participaram da pesquisa. Como mostra o extremo enviesamento da distribuição dos escores associados a este componente, a maioria dos

${ }^{6}$ Por exemplo, o estudante mediano é caracterizado por um escore positivo $(0,23)$, a média sendo igual a zero. 
respondentes é totalmente favorável ao aumento do investimento público em saúde, educação e políticas de luta contra as desigualdades.

\section{Gráfico 1 - Histogramas da distribuição dos escores dos principais componentes}
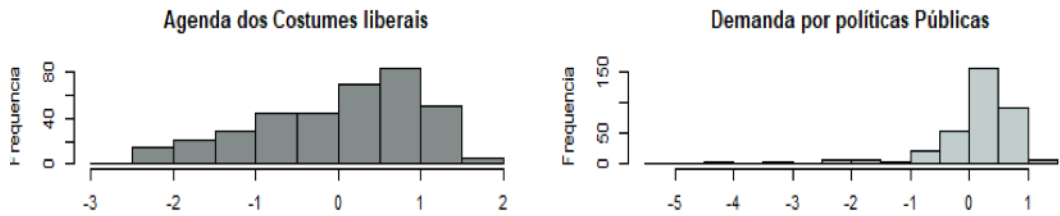

Demanda por Redistribuição

Individualismo Competitivo
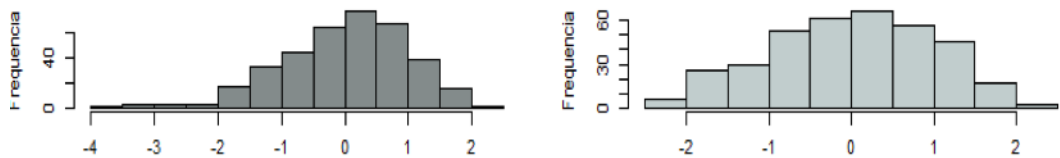

Centralidade da Familia

Estado como Problema

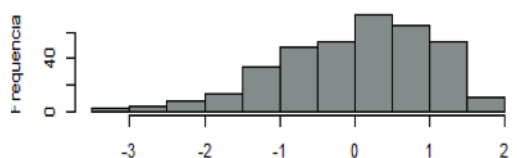

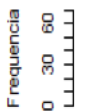

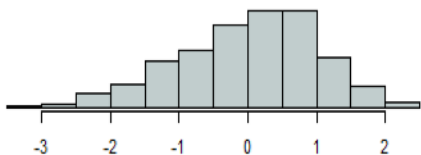

Fonte: Elaboração própria a partir dos dados do survey.

O terceiro componente expressa uma demanda por redistribuição. Este componente apresenta semelhança com as demandas por proteção social, no entanto, não se confundindo com estas. Com efeito, se a demanda 
por proteção social reflete um consenso em prol do envolvimento do Estado na produção de bens públicos como saúde, educação e maiores oportunidades para todos, a demanda por redistribuição manifesta o apoio a políticas como o Bolsa Família, programas de ação afirmativa ou maior tributação dos estratos de renda elevados, que tem impacto em grupos sociais específicos.

O que pode ser qualificado como individualismo competitivo representa o quarto componente extraído do survey. Essa dimensão está associada à valorização do desempenho individual e dos ganhos monetários. Não é estranho, também, que esta dimensão tenda a considerar que o desenvolvimento é, antes de mais nada, fruto dos esforços empresariais. Cabe ainda observar que a distribuição dos escores individuais desse componente é bastante simétrica em torno da média. Indica, portanto, que o número de jovens que aderem aos valores que caracterizam essa dimensão é quase equivalente ao dos que os rejeitam.

O quinto componente, que poderia ser denominado primazia da família e do coletivo, por traduzir a importância dos laços familiares e outros laços sociais fortes na vida desses jovens, é também bastante difundido e aceito. O gráfico 1 mostra, por exemplo, uma distribuição positivamente enviesada, a mediana $(0,14)$ sendo superior à média amostral. O survey sinaliza, dessa forma, a existência de uma concordância difusa com as ideias de que pais e filhos deveriam passar o maior tempo possível juntos, mesmo que isso implique sacrifícios pessoais, ou de que é importante respeitar as decisões dos grupos sociais nos quais se está inserido.

Por fim, a análise dos componentes principais identificou a presença de uma disseminada opinião negativa a respeito do Estado. Considerado burocrático, predatório e de maneira geral como uma restrição ao desenvolvimento, o Estado aparece para muitos antes um problema do que uma solução, embora (paradoxalmente) exista uma ampla demanda por políticas públicas e maior oferta de bens públicos. Essa dimensão pode ser denominada Estado como problema. 
Tabela 6 - Análise dos componentes principais. Componente: carregamento dos fatores $(\operatorname{corte}=\mathbf{0 . 4})$

\begin{tabular}{|c|c|c|c|c|c|c|}
\hline & 1 & 2 & 3 & 4 & 5 & 6 \\
\hline Você é a favor da descriminalização da Maconha? & 0,84 & & & & & \\
\hline $\begin{array}{l}\text { Você é a favor do casamento ou união civil e afetiva } \\
\text { entre pessoas do mesmo sexo? }\end{array}$ & 0,80 & & & & & \\
\hline Você é a favor do aborto? (independente do caso) & 0,77 & & & & & \\
\hline Você é a favor da descriminalização das drogas? & 0,72 & & & & & \\
\hline $\begin{array}{l}\text { Você acha que o homem é naturalmente o chefe } \\
\text { do lar? }\end{array}$ & $-0,68$ & & & & & \\
\hline $\begin{array}{l}\text { Você acha que responsabilidade pela educação } \\
\text { dos filhos é dever primeiro da mulher? }\end{array}$ & $-0,55$ & & & & & \\
\hline $\begin{array}{l}\text { Você é favorável a maior envolvimento do Estado } \\
\text { para melhorar a educação? }\end{array}$ & & 0,92 & & & & \\
\hline $\begin{array}{l}\text { Você é a favor do maior envolvimento do Estado } \\
\text { para melhorar a saúde? }\end{array}$ & & 0,91 & & & & \\
\hline $\begin{array}{l}\text { Você é favorável a um maior envolvimento do } \\
\text { Estado para diminuir as desigualdades sociais? }\end{array}$ & & 0,84 & & & & \\
\hline $\begin{array}{l}\text { Você é favorável às políticas de aumento do salário } \\
\text { mínimo? }\end{array}$ & & 0,57 & & & & \\
\hline Você é a favor da liberalização do porte de armas? & & $-0,45$ & & & & \\
\hline $\begin{array}{l}\text { Você considera que as mulheres deveriam poder } \\
\text { ter uma idade mínima para se aposentar inferior } \\
\text { a dos homens? }\end{array}$ & & & 0,70 & & & \\
\hline $\begin{array}{l}\text { Você concorda com políticas de ação afirmativa } \\
\text { como programas de cotas para alunos grupos } \\
\text { específicos classificados por etnia, na maioria das } \\
\text { vezes, negros e indígenas? }\end{array}$ & & & 0,59 & & & \\
\hline $\begin{array}{l}\text { Você é a favor de políticas de transferências de } \\
\text { renda como o bolsa família? }\end{array}$ & 0,41 & & 0,59 & & & \\
\hline $\begin{array}{l}\text { Você é favorável ao aumento dos impostos para as } \\
\text { camadas sociais mais ricas da sociedade }\end{array}$ & & & 0,53 & & & \\
\hline $\begin{array}{l}\text { Você concorda com a expressão "são os empresários } \\
\text { os maiores responsáveis pelo desenvolvimento } \\
\text { de um país"? }\end{array}$ & & & $-0,47$ & & & \\
\hline $\begin{array}{l}\text { Você acredita que a ascensão social depende } \\
\text { fundamentalmente do esforço individual }\end{array}$ & & & $-0,42$ & & & \\
\hline \multicolumn{7}{|l|}{$\begin{array}{l}\text { Você acredita que é possível ser rico sem ser } \\
\text { pecador? }\end{array}$} \\
\hline \multicolumn{7}{|l|}{$\begin{array}{l}\text { Você é favorável ao estabelecimento de uma idade } \\
\text { mínima ( } 65 \text { anos) para a aposentadoria? }\end{array}$} \\
\hline $\begin{array}{l}\text { Acender profissionalmente significa ganhar mais } \\
\text { do que se ganha hoje? }\end{array}$ & & & & 0,69 & & \\
\hline
\end{tabular}


(cont.)

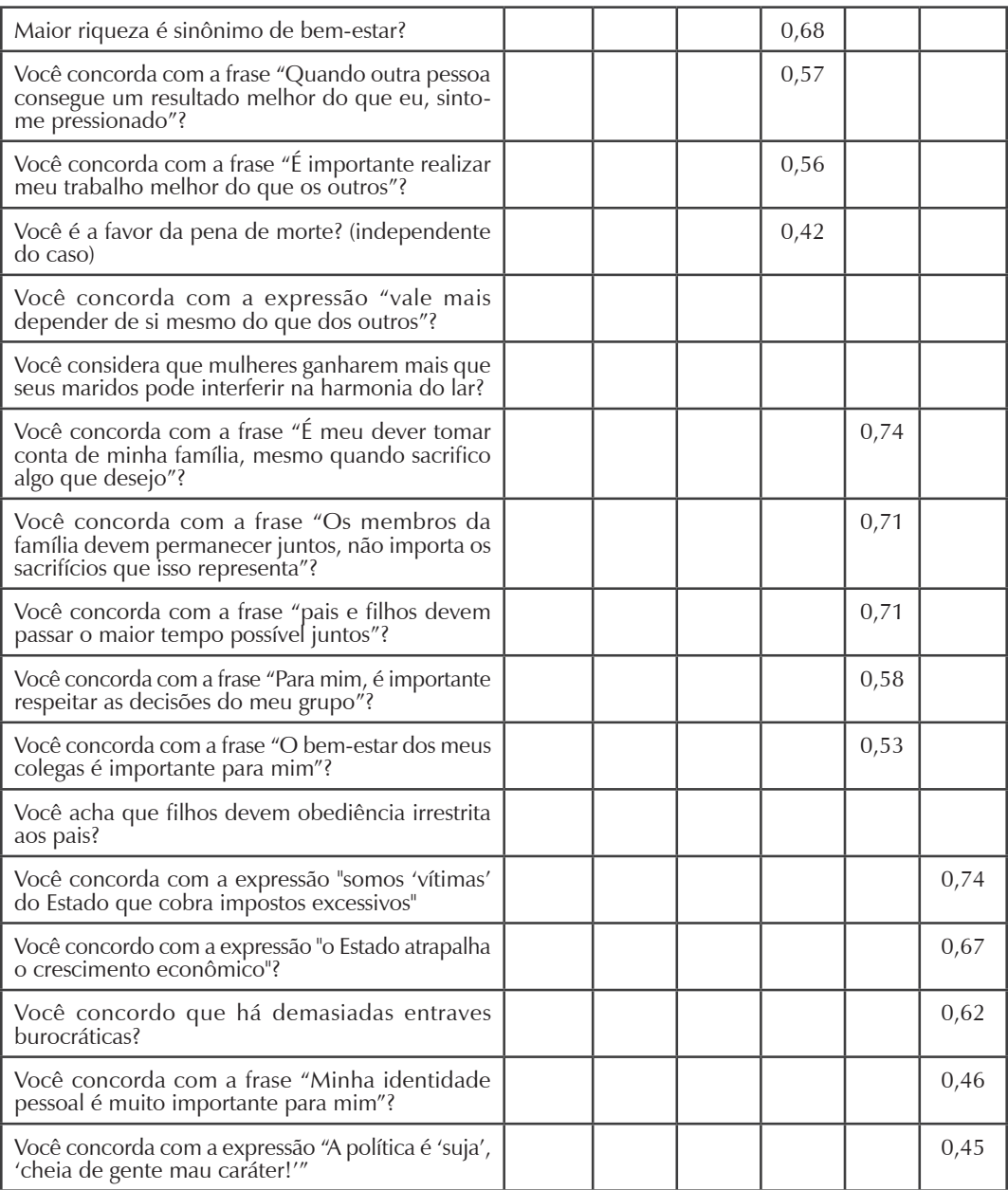

Fonte: Elaboração própria a partir dos dados do survey.

No seu conjunto, a análise dos componentes principais mostra que alguns elementos norteadores da relação entre evangélicos e a "onda conservadora" analisada por Almeida (2017) - sobretudo, a regulação da moral - são elementos que estruturam as atitudes desses jovens universitários. 
Revela, também, a importância dos fatores que tornam suas vidas difíceis, como a precária oferta de bens públicos e o sentimento de que a sociedade é desigual.

\section{Análise de clusters}

O segundo passo da análise do survey consistiu em identificar grupos de estudantes que se caracterizaram por apresentar atitudes sociais e políticas similares (ou dissimilares). Como se distribui a estrutura de preferência? Se existem algumas semelhanças nítidas entre grupos de universitários, será que essas semelhanças têm um perfil social específico?

Para responder essas questões recorreu-se à análise de clusters kmeans, uma técnica multivariada de agrupamento não hierárquica que mede a distância (i.e., dissimilaridade) de uma observação em relação a um centro (centroide), sendo os centros definidos em função do número de clusters escolhidos pelos pesquisadores. Em relação ao survey, o número de clusters selecionados se baseou no método conhecido como Silhouette clustering, uma medida de qualidade de uma partição de um conjunto de dados. $\mathrm{O}$ gráfico 2 indica que o número de agrupamentos básicos mais adequados para classificar os estudantes é dois.

As tabelas 7 a 11 a seguir informam a distribuição relativa dos estudantes entre os dois agrupamentos segundo sua denominação religiosa, estrato de renda familiar, cor, idade e gênero (ver tabelas 7, 8, 9, 10 e 11).

Como pode ser notado, a denominação religiosa é o principal fator de agrupamento dos estudantes, dadas as preferências manifestadas no survey. A tabela 7 mostra a distribuição relativa das denominações entre os dois clusters e, de forma clara, observou-se a existência de um forte contraste: os estudantes evangélicos pertenciam principalmente a um agrupamento diferente daqueles que aderem ao espiritismo kardecista, às religiões afrobrasileiras, a múltiplos pertencimentos ou se declaram sem religião. Quase 75\% dos evangélicos da amostra são classificados como membros do segundo cluster, enquanto mais de $75 \%$ dos sem religião, kardecistas, de denominações afrobrasileiras ou de múltiplos pertencimentos 
são localizados no primeiro agrupamento. Cabe notar que os estudantes católicos se distribuem em semelhante proporção entre os dois clusters, um sinal da importante variabilidade das atitudes por eles manifestadas.

Gráfico 2 - Número ótimo de clusters segundo "Silhouette analysis"

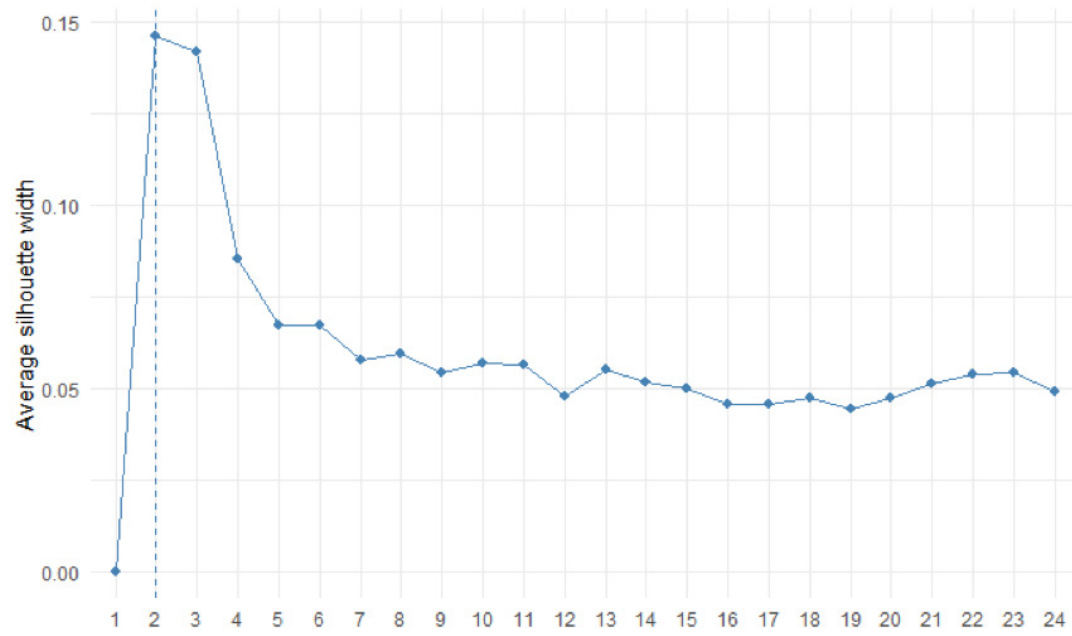

Fonte: Elaboração própria a partir dos dados do survey.

Tabela 7 - Distribuição percentual das denominações religiosas segundo os clusters

\begin{tabular}{|c|c|c|}
\hline & \multicolumn{2}{|c|}{ Clusters } \\
\hline & $\mathbf{1}$ & $\mathbf{2}$ \\
\hline C & 48,08 & 51,92 \\
\hline E & 26,72 & 73,28 \\
\hline K & 78,95 & 21,05 \\
\hline Multi & 85,29 & 14,71 \\
\hline Afro & 80,00 & 20,00 \\
\hline SR & 76,99 & 23,01 \\
\hline
\end{tabular}

Fonte: Elaboração própria a partir dos dados do survey. 
No que tange aos demais atributos, como renda familiar, faixa etária, cor ou gênero, há bastante semelhança entre os estudantes. No entanto, alguns poucos contrastes merecem ser destacados. Um deles está relacionado à dimensão geracional. Os dados parecem indicar que quanto maior a idade, maior a frequência de estudantes situados no segundo cluster. Diferentemente, os de famílias com maior poder aquisitivo tendem a se posicionar mais frequentemente no primeiro cluster. Todavia, tratando-se de grupos de estudantes (mais velhos e de maior poder aquisitivo) com menor representatividade amostral, é arriscado tecer considerações mais gerais a partir desses resultados, ainda que eles estejam, como vimos anteriormente, em concordância com diversos argumentos expostos na literatura especializada.

Tabela 8 - Distribuição percentual da renda familiar segundo os clusters

\begin{tabular}{|c|c|c|}
\hline & \multicolumn{2}{|c|}{ Clusters } \\
\hline Renda & $\mathbf{1}$ & $\mathbf{2}$ \\
\hline B & 64,71 & 35,29 \\
\hline C & 54,37 & 45,63 \\
\hline D & 53,44 & 46,56 \\
\hline E & 57,29 & 42,71 \\
\hline
\end{tabular}

Fonte: Elaboração própria a partir dos dados do survey.

Tabela 9 - Distribuição percentual das faixas etárias segundo os clusters

\begin{tabular}{|c|c|c|}
\hline & \multicolumn{2}{|c|}{ Clusters } \\
\hline & $\mathbf{1}$ & $\mathbf{2}$ \\
\hline$>\mathbf{3 6}$ & 35,14 & 64,86 \\
\hline $\mathbf{1 8 - 2 5}$ & 59,68 & 40,32 \\
\hline $\mathbf{2 6 - 3 5}$ & 52,56 & 47,44 \\
\hline
\end{tabular}

Fonte: Elaboração própria a partir dos dados do survey. 


\section{Tabela 10 - Distribuição percentual das cores segundo os clusters}

\begin{tabular}{|c|c|c|}
\hline & \multicolumn{2}{|c|}{ Clusters } \\
\hline & $\mathbf{1}$ & $\mathbf{2}$ \\
\hline Branca & 56,71 & 43,29 \\
\hline Indígena & 66,67 & 33,33 \\
\hline Negra & 53,85 & 46,15 \\
\hline Amarelo & 60,00 & 40,00 \\
\hline Parda & 55,12 & 44,88 \\
\hline
\end{tabular}

Fonte: Elaboração própria a partir dos dados do survey.

Tabela 11 - Distribuição percentual dos Gêneros segundo os clusters

\begin{tabular}{|c|c|c|}
\hline & \multicolumn{2}{|c|}{ Clusters } \\
\hline & $\mathbf{1}$ & $\mathbf{2}$ \\
\hline Outros & 100,00 & 0,00 \\
\hline $\mathbf{F}$ & 57,14 & 42,86 \\
\hline $\mathbf{M}$ & 53,10 & 46,90 \\
\hline
\end{tabular}

Fonte: Elaboração própria a partir dos dados do survey.

A análise dos clusters tende a corroborar, de forma evidentemente modesta, as contribuições de diversos autores (Machado, 2015; Almeida, 2017; Villazón, 2014; Smith, 2019; Prandi; Santos, 2017) que identificam uma relação entre a identidade evangélica e o conservadorismo moral. Sinaliza, também, um possível efeito geracional na formação de valores seculares, efeito que é provavelmente potencializado pela inserção no ensino superior. Após identificar dois agrupamentos de estudantes e observar que em cada um destes a denominação religiosa é um fator de homogeneidade interna, há de se investigar se os dois agrupamentos apresentam estruturas de preferências distintas ou semelhantes. 


\section{Religião, preferências e características dos estudantes}

A existência de relações entre agrupamentos e estrutura de preferências deve traduzir o fato de que estudantes de agrupamentos diferentes informam preferências diferentes. O gráfico 3 apresenta a estrutura de preferências dos estudantes em um plano bidimensional, no qual o eixo horizontal informa os escores individuais no tocante à agenda de costumes liberais o primeiro e mais importante componente principal - e os eixos verticais seus posicionamentos nas demais dimensões reveladas anteriormente. Além disso, o gráfico 3 classifica os estudantes em função dos seus agrupamentos respectivos. Aqueles situados no primeiro agrupamento são associados à cor vermelha, enquanto os do segundo são representados pela cor azul. Percebe-se logo que os membros do primeiro são muito mais propensos a concordar com uma agenda liberal de costumes do que os do segundo.

Nas demais dimensões das preferências, graficamente representadas pelo eixo vertical, não parece haver diferenças significativas entre os membros dos dois agrupamentos. Levando em conta as características destes, assim como os argumentos da literatura especializada destacada anteriormente, supõe-se que a denominação religiosa é um fator que tem uma importância significativa no grau de adesão e rejeição à agenda de costumes liberais, mas que deixa de ter tanta relevância quando se consideram as outras dimensões das preferências.

Para aprofundar a análise das relações entre denominação religiosa e preferências políticas e sociais dos estudantes, uma análise de regressão é útil. Os resultados dos modelos de mínimos quadrados ordinários (MQO) que analisam essas relações são apresentados na tabela 12.

No modelo 1, a variável dependente é o conjunto de escores individuais que representam o primeiro componente, isto é, a agenda dos costumes liberais. As variáveis independentes são a denominação religiosa, a renda, a cor, a faixa etária e o gênero. Nos demais modelos, as variáveis independentes permanecem as mesmas, enquanto mudam os escores nas demais dimensões das preferências destacadas pela análise dos componentes principais. No modelo 2, por exemplo, encontram-se 
os escores do componente que traduz a demanda por políticas públicas e proteção social, que servem de variáveis dependentes. No modelo 3 estão os escores da preferência por redistribuição. O modelo 4, por sua vez, leva em conta o grau de valorização do individualismo e da competição social. O modelo 5 demonstra as variações da adesão aos valores da primazia do grupo e da família. O modelo 6, por fim, tem por foco a crença no Estado como problema.

Gráfico 3 - Visualização dos clusters em função dos componentes principais
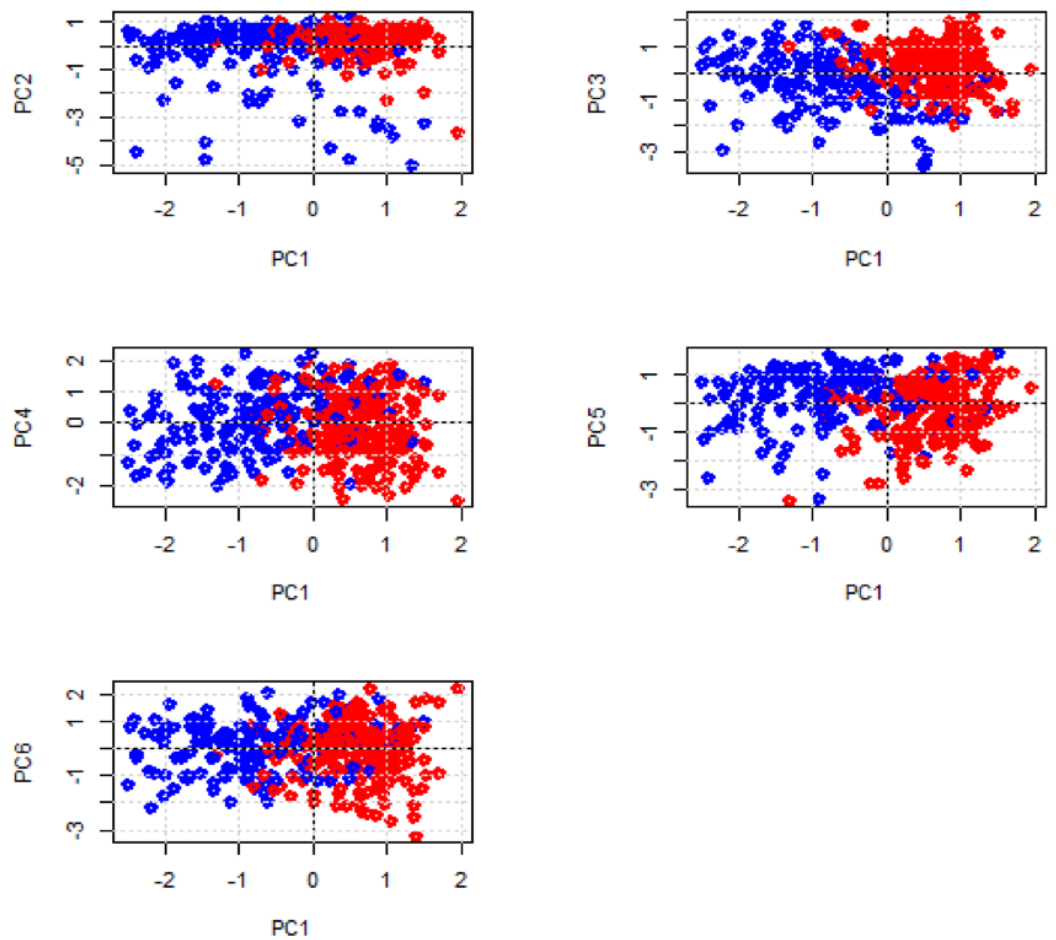

Fonte: Elaboração própria a partir dos dados do survey. 
Tabela 12 - Modelos de regressão para os diferentes componentes

\begin{tabular}{|c|c|c|c|c|c|c|}
\hline & \multicolumn{6}{|c|}{ Escores dos Componentes Principais } \\
\hline & PC1 & PC2 & PC3 & PC4 & PC5 & PC6 \\
\hline \multirow[t]{2}{*}{ Religião E } & $-0,71 * * *$ & $-0,16$ & $0,32 *$ & $-0,10$ & 0,15 & $-0,12$ \\
\hline & $(0,13)$ & $(0,16)$ & $(0,17)$ & $(0,17)$ & $(0,17)$ & $(0,16)$ \\
\hline \multirow[t]{2}{*}{ Religião K } & $0,44^{* *}$ & $-0,15$ & $0,49 *$ & 0,37 & $-0,44$ & 0,34 \\
\hline & $(0,22)$ & $(0,27)$ & $(0,27)$ & $(0,28)$ & $(0,27)$ & $(0,27)$ \\
\hline \multirow[t]{2}{*}{ Religião M.R. } & $0,48^{* * *}$ & 0,18 & $0,58^{* * *}$ & 0,07 & $-0,27$ & $-0,01$ \\
\hline & $(0,18)$ & $(0,22)$ & $(0,22)$ & $(0,23)$ & $(0,22)$ & $(0,22)$ \\
\hline \multirow[t]{2}{*}{ Religião Afro } & 0,29 & 0,06 & 0,40 & 0,16 & $-0,40$ & $-0,20$ \\
\hline & $(0,23)$ & $(0,29)$ & $(0,29)$ & $(0,30)$ & $(0,29)$ & $(0,28)$ \\
\hline \multirow[t]{2}{*}{ Religião SR } & $0,58^{* * *}$ & $-0,12$ & $0,28^{*}$ & 0,10 & $-0,43^{* *}$ & $-0,13$ \\
\hline & $(0,13)$ & $(0,17)$ & $(0,17)$ & $(0,17)$ & $(0,17)$ & $(0,16)$ \\
\hline \multirow[t]{2}{*}{ Renda C } & $-0,003$ & $-0,01$ & $-0,01$ & $-0,34 *$ & $-0,17$ & 0,16 \\
\hline & $(0,16)$ & $(0,19)$ & $(0,20)$ & $(0,20)$ & $(0,20)$ & $(0,19)$ \\
\hline \multirow[t]{2}{*}{ Renda D } & $-0,11$ & 0,22 & $-0,18$ & $-0,33^{*}$ & $-0,26$ & $-0,13$ \\
\hline & $(0,15)$ & $(0,19)$ & $(0,19)$ & $(0,20)$ & $(0,19)$ & $(0,19)$ \\
\hline \multirow[t]{2}{*}{ Renda E } & $-0,11$ & 0,22 & 0,12 & $-0,33$ & $-0,21$ & 0,13 \\
\hline & $(0,16)$ & $(0,20)$ & $(0,20)$ & $(0,20)$ & $(0,20)$ & $(0,19)$ \\
\hline \multirow[t]{2}{*}{ COR Indígena } & 0,76 & $-0,13$ & $-0,54$ & $-1,00^{*}$ & 0,22 & $-0,02$ \\
\hline & $(0,46)$ & $(0,58)$ & $(0,58)$ & $(0,60)$ & $(0,58)$ & $(0,57)$ \\
\hline \multirow[t]{2}{*}{ COR Negra } & $-0,04$ & 0,22 & $0,29 *$ & 0,05 & $-0,25^{*}$ & 0,24 \\
\hline & $(0,12)$ & $(0,15)$ & $(0,15)$ & $(0,15)$ & $(0,15)$ & $(0,15)$ \\
\hline \multirow[t]{2}{*}{ COR Amarelo } & 0,41 & $-0,40$ & $-0,29$ & $-0,36$ & $-0,25$ & $-0,80^{*}$ \\
\hline & $(0,36)$ & $(0,44)$ & $(0,45)$ & $(0,46)$ & $(0,45)$ & $(0,44)$ \\
\hline \multirow[t]{2}{*}{ COR Parda } & $-0,17^{*}$ & 0,01 & 0,05 & 0,13 & $-0,30^{* *}$ & 0,16 \\
\hline & $(0,09)$ & $(0,12)$ & $(0,12)$ & $(0,12)$ & $(0,12)$ & $(0,12)$ \\
\hline \multirow[t]{2}{*}{ Idade 18-25 } & $0,78^{* * *}$ & $-0,06$ & $-0,28$ & $-0,06$ & $-0,15$ & $-0,21$ \\
\hline & $(0,14)$ & $(0,18)$ & $(0,18)$ & $(0,19)$ & $(0,18)$ & $(0,18)$ \\
\hline \multirow[t]{2}{*}{ Idade 26-35 } & $0,58^{* * *}$ & $-0,13$ & $-0,21$ & 0,03 & $-0,18$ & $-0,28$ \\
\hline & $(0,16)$ & $(0,20)$ & $(0,20)$ & $(0,21)$ & $(0,20)$ & $(0,20)$ \\
\hline
\end{tabular}


(cont.)

\begin{tabular}{|c|c|c|c|c|c|c|}
\hline \multirow{2}{*}{ Gênero F } & 0,32 & $-0,001$ & $-0,08$ & $-0,63$ & $-0,29$ & $-0,95$ \\
\cline { 2 - 7 } & $(0,56)$ & $(0,70)$ & $(0,71)$ & $(0,72)$ & $(0,70)$ & $(0,69)$ \\
\hline \multirow{2}{*}{ Gênero M } & 0,31 & $-0,53$ & $-0,38$ & $-0,59$ & $-0,07$ & $-1,42^{* *}$ \\
\cline { 2 - 7 } & $(0,56)$ & $(0,70)$ & $(0,71)$ & $(0,72)$ & $(0,70)$ & $(0,69)$ \\
\hline \multirow{2}{*}{ Constant } & $-0,86$ & 0,19 & 0,11 & 0,88 & 0,83 & $1,30^{*}$ \\
\cline { 2 - 7 } & $(0,59)$ & $(0,73)$ & $(0,74)$ & $(0,76)$ & $(0,74)$ & $(0,73)$ \\
\hline $\mathbf{R}^{\mathbf{2}}$ & 0,42 & 0,11 & 0,09 & 0,04 & 0,10 & 0,13 \\
\hline Adjusted R & 0,39 & 0,07 & 0,04 & $-0,002$ & 0,05 & 0,08 \\
\hline $\begin{array}{c}\text { Residual Std. Error (df } \\
=\mathbf{3 4 6 )}\end{array}$ & 0,78 & 0,97 & 0,98 & 1,00 & 0,97 & 0,96 \\
\hline F Statistic (df = 17; 346) & $14,93^{* * *}$ & $2,54^{* * *}$ & $1,95^{* *}$ & 0,96 & $2,17^{* * *}$ & $2,98 * * *$ \\
\hline
\end{tabular}

Fonte: Elaboração própria a partir dos dados do survey.

Em diversos aspectos, os resultados das regressões mostraram que as atitudes dos universitários da Baixada Fluminense são similares àquelas destacadas na literatura especializada. Os evangélicos formam o grupo religioso com maior nível de rejeição à agenda liberal dos costumes. Como apontado por diversos autores (Machado, 2012; Fernandes, 2011), opiniões sobre a legalização do aborto são marcadamente influenciadas pela religião, e, dada a relação entre religiões e grau de religiosidade, não é estranho constatar que, quanto maior a religiosidade, maior a rejeição ao aborto (Machado, 2012).

A importância da religião é também significativa quando se averiguam juízos a respeito de questões como casamento de pessoas do mesmo sexo ou a descriminalização das drogas, fato já destacado por Nishimura (2004) e Bohn (2004). Os evangélicos também se mostraram mais conservadores que os católicos na dimensão dos costumes, porém mais propensos que estes ao apoio a políticas redistributivas, como o Bolsa Família ou programas de cotas para minorias. Nesse quesito, são parecidos com os sem religião.

Outro grupo numericamente importante, o dos sem religião, apresenta maior nível médio de aceitação da agenda liberal dos costumes. Neste 
estão também aqueles que menos concordam em sacrificar suas escolhas individuais em função das decisões coletivas, sejam estas do grupo familiar ou da organização na qual atuam. Os sem religião, os kardecistas, os evangélicos e os estudantes com múltiplos pertencimentos são também os mais favoráveis às políticas redistributivas.

O fato de que os estudantes, independentemente de suas denominações religiosas, manifestam uma demanda por políticas públicas e maior atuação do Estado na provisão de segurança econômica parece corroborar os pontos de vista de Almeida e Young (2007) e Pinheiro e Giambiagi (2006), para quem o brasileiro gosta do Estado - embora seja mais apropriado dizer que o brasileiro, sobretudo, conta com o Estado para melhorar seu padrão de vida, ainda que não o tenha em alta estima.

O elevado grau de aceitação de um aumento dos investimentos do Estado em bens públicos como saúde e educação reflete, também, uma demanda por ações públicas, já destacada por Souza e Lamounier (2009) em seu estudo sobre a cultura política da nova classe média. Para esses autores, existe um amplo consenso a favor da atuação do Estado entre as camadas mais populares da sociedade brasileira, camadas bastante representativas da população das periferias dos grandes centros urbanos do país.

Os modelos de regressão mostram que a diferenciação por estratos de renda ou por cor pouco interfere na variabilidade das preferências dos estudantes que participaram do survey. A renda familiar não apresenta relações estatisticamente significativas, nem com a agenda liberal dos costumes, nem com as demandas por bens públicos e segurança econômica, nem com a adesão a primazia da família. No entanto, constata-se que os estratos de renda C e D, os mais numerosos da amostra, partilham menos das ideias associadas ao individualismo competitivo do que a classe B, sugerindo que o ideário do liberalismo econômico tem menor apelo e justificação nas camadas sociais materialmente mais fragilizadas.

A diferenciação por cor só parece significativa na questão da primazia do grupo e da família. Os estudantes negros e pardos mostram-se menos propensos que os brancos a sacrificar suas escolhas para se adequar às decisões do grupo ou alocar seu tempo para ficar com seus familiares. Esses 
estudantes, que ascenderam socialmente com o acesso à universidade, são provavelmente aqueles para os quais os dilemas entre conformismo familiar e empoderamento individual são mais agudos - dilemas que se traduzem, possivelmente, em menor tolerância às regras familiares e coletivas.

Os jovens são, em geral, politicamente mais progressistas do que seus pais nos países em que a religião é uma esfera importante do dia a dia. Como já evidenciaram diversos autores (Fernandes, 2011; Lindhardt, 2016; Freston, 1998) e diversas pesquisas de opinião realizadas pelo think tank PEW Research Center, os jovens mostram-se mais favoráveis ao casamento de pessoas do mesmo sexo, à liberalização da maconha e até mesmo à legalização do aborto do que as gerações mais velhas. Os dados do survey podem ser interpretados como uma confirmação desse fenômeno mais geral.

Como pode ser notado, as faixas etárias mais jovens são mais propensas a concordar com os temas característicos da agenda liberal dos costumes - uma aceitação que independe do gênero. Por outro lado, nem a idade nem o gênero parecem influenciar outros componentes principais da estrutura de preferência, com a exceção do juízo a respeito do Estado como problema. Nesse ponto, os jovens do gênero masculino estão mais inclinados a concordar com a narrativa de que "somos 'vítimas' de um Estado que 'cobra impostos excessivos'", que se caracteriza por "demasiados entraves burocráticos" e que, definitivamente, "o Estado atrapalha o crescimento econômico".

\section{Conclusões}

Os dados do survey confirmam as principais tendências identificadas pelo censo demográfico brasileiro de 2010, a saber, o avanço dos evangélicos e dos sem religião na periferia do Rio de Janeiro e, de maneira mais geral, nas grandes regiões metropolitanas brasileiras. A análise dos dados confirma também hipóteses formuladas por estudiosos da dinâmica religiosa na América Latina e no Brasil. Os estudantes evangélicos apresentam opiniões mais conservadoras do que os demais em temas polêmicos como legalização do aborto, casamento de pessoas do mesmo sexo ou liberalização da 
maconha. Todavia, o survey convida a um reexame dos argumentos da primazia da família ou do posicionamento mais libertário e pró-mercado dos evangélicos. As atitudes dos estudantes da Baixada Fluminense refletem certamente suas vivências dos múltiplos "altares" da modernidade (Berger, 2016), nos quais valores seculares e religiosos se mesclam e não se enquadram facilmente em grandes categorias sociais, econômicas ou políticas (Hervieu-Léger, 1985).

Mais especificamente, os dados mostram a existência de um grupo formado predominantemente por evangélicos com opiniões moralmente mais conservadoras do que a média dos jovens da Baixada Fluminense. Todavia, o survey indica a existência de um número significativo de jovens favoráveis a uma agenda mais progressista e menos sujeita a aceitar os valores tradicionais. Nesse grupo, predominam aqueles que informam não ter religião, ainda que a metade deles acredite na existência de algum deus.

A percepção desses jovens do papel do Estado é ambígua. O survey confirma a hipótese de que em termos do posicionamento sobre políticas sociais, não existem diferenças significativas entre os respondentes. Quase todos os estudantes apoiam políticas que aumentam os investimentos em educação, saúde e segurança econômica. Porém, há um sentimento difuso de que o Estado é excessivamente burocratizado, cobra demasiados impostos e, provavelmente, é incapaz de atender de forma adequada às demandas sociais. Além disso, existe uma forte desconfiança de sua capacidade de promover o crescimento econômico, este que tampouco se espera ser promovido pelos empresários.

$\mathrm{Na}$ intensa crise política e econômica pela qual passa o Brasil, o jovem da periferia das grandes cidades não parece acreditar nem que o desenvolvimento será promovido pelo Estado, nem que a solução virá do mercado. Ele aparenta descontentamento e certa perplexidade diante do volume de informações que retratam a política como uma arena povoada por corruptos e corruptores e sonha com um Estado mais capaz, acessível e de qualidade e com um mercado mais dinâmico, inclusivo e socialmente responsável. 
A influência significativa da idade em questões de costumes pode indicar que as gerações mais novas se sentem mais confortáveis moralmente com temas como a legalização do aborto, o casamento de pessoas do mesmo sexo ou a liberalização da maconha. São questões sociais polêmicas, mas que, possivelmente, num futuro não tão distante, sejam bem mais aceitas pela maioria dos eleitores, mesmo entre aqueles pertencentes a denominações evangélicas. Com um aumento do grau de escolarização e do acesso ao ensino superior, é também muito provável que essa tendência se fortaleça.

Por fim, não obstante serem limitados, por terem por base um universo composto por indivíduos jovens e com maior nível de instrução do que a mediana da população da Baixada Fluminense, os resultados apresentados apontam tendências que provavelmente influenciarão as agendas políticas e estratégias eleitorais de 2020. Assim, apesar dessa limitação, proporcionam mais uma evidência de que tanto a expansão dos evangélicos como o processo de secularização da sociedade serão dois componentes centrais da ética do capitalismo brasileiro.

Georges Gérard Flexor é Doutor em Ciências Sociais em Desenvolvimento, Agricultura e Sociedade e professor da Universidade Federal Rural do Rio de Janeiro.

$\equiv$ gflexor@gmail.com

Adrianno Oliveira Rodrigues é Doutor em Planejamento Urbano e Regional e professor adjunto da Universidade Federal Rural do Rio de Janeiro.

$\equiv$ adriannooliveira@yahoo.com.br

Robson Dias da Silva é Doutor em Desenvolvimento Econômico e professor associado da Universidade Federal Rural do Rio de Janeiro

$\equiv$ robsondsilva@gmail.com 


\section{Referências}

1. ALMEIDA, Alberto C.; YOUNG, Clifford A. A cabeça do brasileiro. Rio de Janeiro: Record, 2007.

2. ALMEIDA, Ronaldo de. A onda quebrada: evangélicos e conservadorismo. Cadernos Pagu, n. 50, 2017. http://dx.doi.org/10.1590/180944492017005000 01

3. ALVES, José E.; CAVENAGHI, Suzana; BARROS, Luiz F.; CARVALHO, Angelita A. de. Distribuição espacial da transição religiosa no Brasil. Tempo Social, v. 29, n. 2, p. 215-242, 2017. http://dx.doi.org/10.11606/0103-2070.ts.2017.112180

4. AZZI, Corry; EHRENBERG, Ronald. Household allocation of time and church attendance. Journal of Political Economy, v. 83, n. 1, p. 27-56, 1975.

5. BERGER, Peter L. Múltiplos altares da modernidade. Petrópolis: Editora Vozes, 2016.

6. BOHN, Simone R. Evangélicos no Brasil: perfil socioeconômico, afinidades ideológicas e determinantes do comportamento eleitoral. Opinião Pública, v. 10, n. 2, p. 288-338, 2004. http://dx.doi.org/10.1590/S0104-62762004000200006

7. BOHN, Simone R. Contexto político-eleitoral, minorias religiosas e voto em pleitos presidenciais (2002-2006). Opinião pública, v. 13, n. 2, p. 366-387, 2007. http://dx.doi.org/10.1590/S0104-62762007000200006

8. CAMURÇA, Marcelo A. O Brasil religioso que emerge do Censo de 2010: consolidações, tendências e perplexidades. In: TEIXEIRA, Faustino; MENEZES, Renata (orgs.). Religiões em movimento: o Censo de 2010. Petrópolis: Vozes, 2013. p. 63-87.

9. CHESNUT, Andrew R. Competitive spirits: Latin America's new religious economy. Oxford: Oxford University Press, 2003.

10. FERNANDES, Silvia R. A. Marcos definidores da condição juvenil para católicos e pentecostais na baixada fluminense - algumas proposições a partir de um survey. Religião \& Sociedade, v. 31, n. 1, p. 96-125, 2011. http://dx.doi. org/10.1590/S0100-85872011000100005

11. FRESTON, Paul. Pentecostalism in Latin America: characteristics and controversies. Social Compass, v. 45, n. 3, p. 335-358, 1998. https://doi. org/10.1177/003776898045003002

12. GILL, Anthony. Weber in Latin America: is protestant growth enabling the consolidation of democratic capitalism? Democratization, v. 11, n. 4, p. 42-65, 2004. https://doi.org/10.1080/1351034042000234521

13. HERVIEU-LÉGER, Danièle. Sécularisation et modernité religieuse. Esprit, n. 106, p. 50-62, out. 1985. Disponível em: https://www.jstor.org/stable/24270796.

14. IANNACCONE, Laurence R. Introduction to the economics of religion. Journal of Economic Literature, v. 36, n. 3, p. 1465-1495, 1998. Disponível em: https://www.jstor.org/stable/2564806 
15. JACOB, Cesar R.; HEES, Dora R.; WANIEZ, Philippe. Religião e território no Brasil: 1991/2010. Rio de Janeiro: Editora PUC-Rio, 2013.

16. LACERDA, Fabio. Evangelicals, pentecostals and political representation in Brazilian legislative elections (1998-2010). Revista Brasileira de Ciências Sociais, v. 32, n. 93, Epub, 2017. http://dx.doi.org/10.17666/329310/2017

17. LACERDA, Fábio; BRASILIENSE, José M. Brasil: la incursión de los pentecostales en el poder legislativo brasileño. In: GUADALUPE, José L. P.; GRUNDBERGER, Sebastian (orgs.). Evangélicos y Poder en América Latina. Berlim: Konrad Adenauer Stiftung, 2018. p. 141-180.

18. LINDHARDT, Martin. New ways of being Pentecostal in Latin America. Washington DC: Lexington Books, 2016.

19. MACHADO, Maria D. C. Aborto e ativismo religioso nas eleições de 2010. Revista Brasileira de Ciência Política, n. 7, p. 25-54, 2012. http://dx.doi. org/10.1590/S0103-33522012000100003

20. MACHADO, Maria D. C. Religião e política no Brasil contemporâneo: uma análise dos pentecostais e carismáticos católicos. Religião \& Sociedade, v. 35, n. 2, p. 45-72, 2015. http://dx.doi.org/10.1590/0100-85872015v35n2cap02

21. MARIANO, Ricardo. Neopentecostais: sociologia do novo pentecostalismo no Brasil. São Paulo: Edições Loyola, 1999.

22. MARIANO, Ricardo. Expansão pentecostal no Brasil: o caso da Igreja Universal. Estudos Avançados, v. 18, n. 52, p. 121-138, 2004. http://dx.doi.org/10.1590/ S0103-40142004000300010

23. MARIANO, Ricardo. Crescimento pentecostal no Brasil: fatores internos. Revista de Estudos da Religião, ano 8, n. 4, p. 68-95, dez. 2008.

24. MARIANO, Ricardo. Sociologia do crescimento pentecostal no Brasil: um balanço. Perspectiva Teológica, v. 43, n. 119, p. 11-36, 2011. https://doi. org/10.20911/21768757v43n119p11/2011

25. MARIANO, Ricardo. Mudanças no campo religioso brasileiro no censo 2010. Debates do NER, v. 2, n. 24, p. 119-137, 2013. https://doi.org/10.22456/19828136.43696

26. MARIANO, Ricardo. Expansão e ativismo político de grupos evangélicos conservadores. Secularização e pluralismo em debate. Civitas-Revista de Ciências Sociais, v. 16, n. 4, p. 710-728, 2016. http://dx.doi.org/10.15448/19847289.2016.4.25765

27. MENEZES, Renata C. Censo 2010, fotografia panorâmica da vida nacional. (Entrevista a Thamiris Magalhães, agosto/ 2012). IHU On-Line, n. 400, ano XII, 2012.

28. NERI, Marcelo C. A nova classe média: o lado brilhante da base da pirâmide. São Paulo: Editora Saraiva, 2011. 
29. NISHIMURA, Katia M. Conservadorismo social: opiniões e atitudes no contexto da eleição de 2002. Opinião Pública, v. 10, n. 2, p. 339-367, 2004. http://dx.doi.org/10.1590/S0104-62762004000200007

30. PEIXOTO, Vitor; RENNÓ, Lucio. Mobilidade social ascendente e voto: as eleições presidenciais de 2010 no Brasil. Opinião Pública, v. 17, n. 2, p. 304-332, 2011. http://dx.doi.org/10.1590/S0104-62762011000200002

31. PINHEIRO, Armando C.; GIAMBIAGI, Fábio. Rompendo o marasmo: a retomada do desenvolvimento no Brasil. Rio de Janeiro: Elsevier, 2006.

32. PRANDI, Reginaldo; DOS SANTOS, Renan W. Quem tem medo da bancada evangélica? Posições sobre moralidade e política no eleitorado brasileiro no Congresso Nacional e na Frente Parlamentar Evangélica. Tempo Social, v. 29, n. 2, p. 187-213, 2017. http://dx.doi.org/10.11606/0103-2070.ts.2017.110052

33. SCALON, Celi; SALATA, André. Uma nova classe média no Brasil da última década? O debate a partir da perspectiva sociológica. Sociedade e Estado, v. 27, n. 2, p. 387-407, 2012. http://dx.doi.org/10.1590/S0102-69922012000200009

34. SOUZA, Jessé. Os batalhadores brasileiros: nova classe média ou nova classe trabalhadora? Belo Horizonte: Editora UFMG, 2012.

35. SOUZA, Amaury; LAMOUNIER, Bolívar. A classe média brasileira: ambições, valores e projetos de sociedade. Rio de Janeiro: Elsevier, 2009.

36. SMITH, Amy E. Religion, politics, and the secular State. In: AMES, Barry (org.). Routledge handbook of Brazilian politics. Abingdon: Routledge, 2018. p. 87 102.

37. SMITH, Amy E. Religion and Brazilian democracy: mobilizing the people of God. Cambridge: Cambridge University Press, 2019.

38. STARK, Rodney. Economics of religion. In: SEGAL, Robert A. The blackwell companion to the study of religion. Hoboken: Wiley-Blackwell, 2009. p. 47-68.

39. TEIXEIRA, Faustino. Os dados sobre religiões no Brasil em debate. Debates do NER, v. 2, n. 24, p. 77-84, 2013. https://doi.org/10.22456/1982-8136.43690

40. TEIXEIRA, Faustino; MENEZES, Renata. Religiões em movimento: o Censo de 2010. Petrópolis: Editora Vozes, 2014.

41. UCHOA, Christiane; KERSTENETZKY, Celia L. É a "nova classe média" classe média? O que diz a Pesquisa de Orçamentos Familiares (2008-2009). CEDE, Texto para Discussão n. 66, Universidade Federal Fluminense, 2012.

42. VILLAZÓN, Julio C. Viejas y nuevas derechas religiosas en América Latina: los evangélicos como factor político. Nueva Sociedad, n. 254, p. 112-123, 2014.

Recebido em: 29 jul. 2019. Aceito em: 23 out. 2019. 